\title{
The Influence of Motivation, Discipline, Work Satisfaction and Company Environment to Employees Performance of PT Profab Indonesia
}

\author{
Decky Antony Kifta \\ Student of Magister of Management, Universitas Riau Kepulauan, \\ Jl. Batu Aji Baru No. 99, Kota Batam, Kepulauan Riau. \\ email: deckyantoni@gmail.com
}

\begin{abstract}
The purpose of this study is to understand the influence between motivation, discipline, work satisfaction and company environment with employees performance in PT Profab Indonesia. As understood that employees are company's asset therefore improving employee's performance will lead to improvement of company's productivity. There are four elements or variables which are believed to influence employee's performance. These variables are motivation, discipline, work satisfaction and company environment. To obtain the required data, the observer used some methods such as interviews, observations and distributing the questionnaires. The questionnaires were made based on the four independent variables and one dependent variable. There were 200 employees selected as respondents to fill the questionnaires, and the data obtained were analyzed using SPSS program. Tests were made using statistical methods i.e. descriptive analysis, prerequisite analytical test, $t$-test, F-test, multiple linear regressions and coefficients determination. The results obtained from the statistical analysis gives the conclusion and proves that there was significant correlation between the motivation, discipline, work satisfaction and company environment with employee's performance either partially or simultaneously. This was shown in coefficient correlation value of 0.919 which is equal to 'very strong' and the value of adjusted $R$ square of 0.841 or $84.1 \%$, which means that the influence of motivation, discipline, work satisfaction and company environment toward employees' performance is very strong, with the percentage of $84.1 \%$.
\end{abstract}

Keywords: Motivation, Discipline, Work Satisfaction, Company Environment, Employees Performance

\section{INTRODUCTION}

Human capital or human resources are the most important issue in the organization or corporation. In order to work well, therefore, the corporate need manage its human resources activities in professional way. Employees with good talents, knowledges, skills and willingness to work well can be good asset for the company and hence needed to improve its productivity. Amstrong and Baron (1998) in Wibowo (2017:2) defined the performance as the results of employees' activities which are in line with company mission, strategy and targets. Good employees' performance not only gives benefits to the company but also it gives value to the customers, and their satisfaction when using the products or services, which at the end will also affect the employee's welfare within the company. There are several factors which are believed to have influences on the ups-and-downs of the employee's performances and among others are motivation, discipline, work satisfaction dan company environment, which were raised by the writer in this research. 
This research is to discuss the influences of motivation, discipline, work satisfaction and company environment to the employees' performance of PT Profab Indonesia, because PT Profab Indonesia is a foreign investment company located in Indonesia and operates in the fabrication of equipment and facilities for Offshore and Onshore Oil and Gas fields. This research was using purpose sampling with 200 respondents from 400 people population of the employees working on site. The numbers of responded was taken using Slovin formula.

To obtain the data for the research, questionnaires were distributed to the respondents and the questionnaires were comprising four independent variables (i.e. motivation, discipline, work satisfaction dan company environment), and one dependent variable i.e. employees' satisfaction. The results gathered from the filled questionnaires then be compiled and analyzed using SPSS program, and SPSS version 21 was used to process the data.

\section{MATERIALS AND METHODS}

\subsection{Motivation}

According to Robbins (2013:202) that motivation is the way to satisfy and suffice one's need, while Masrukhin and Waridin (2006) in Walsa and Ratnasari, believed that motivation is psychological factor which shows the one's interest towards his/her works which includes work satisfaction and responsibilities, this will be reflected in his/her daily routine works. Motivation, according to Nawawi (2008) as highlighted by Suprihati (2014) is the condition which drives an employee perform his/her works consciously. Herzberg (1996) in his theory, as written by Wijayanto (2012:151) divided this motivation into two factors, i.e. motivator factor (intrinsic motivation) and hygiene factor (extrinsic motivation). Moreover Suprihati (2014) stated that motivation can emerge from the inside of individual (intrinsically) and can also be driven from outside of the individual (extrinsically).

\subsection{Discipline}

Many scholars defined that discipline is the awareness and willingness of an employee to obey and follow the company or organization's rules and regulations, including their acknowledged social norms (Hasibuan, 2016:193). Sutrisno (2014) as highlighted by Supomo and Nurhayati (2018:133) explained that discipline is one's behavior which is inline with written or verbal rules and work procedures specified by an organization or company. Other insights came from Simamora (2006) in Sukadi (2016:24), which specified that discipline is a procedure to correct or judge the subordinates who violate the rules or certain procedures imposed by an organization or company. Siswanto (2003) in Supomo and Nurhayati (2018:139) explained that the intention to impose the disciplinary action to the employees is to maintain the company survival and to comply with company strategic plan and goals. According to Handoko (2010:208) there are two types of discipline activities and they are as below:
a) Preventive Discipline
This discipline activity is done to drive the employees to follow the rules and regulations, so the misconducts can be avoided or prevented.
b) Corrective Discipline 
This type of discipline activity is taken to handle the disorder or violation to the set rules and regulations. Corrective action is taken to give punishment or sanctions to the people who disobey the rules or regulations. This action is sometimes called as disciplinary action.

\subsection{Work Satisfaction}

Robbins (2013:74) defined the work satisfaction as the common attitude of individuals towards their jobs. Robbins disclosed that many managers believed that their satisfied workers would be more productive than those that were not. Gathungu et al. (2013) defined that work satisfaction is the feeling of happiness within the employees as the results that their jobs can suffice what they need and give values to themselves. Mangkunegara (2005) as highlighted by Sulasri and Suhardi (2017) concluded that work satisfaction is the feeling of supporting within the employee which is connecting to his/her job and his/her condition. The work satisfaction is the result of evaluation which describes employee's happiness or unhappiness, satisfaction or dissatisfaction towards his/her job assignments.

\subsection{Company Environment}

According to Dame (2009) as quoted by Bianca and Susihono (2012), that organization environment or company environment describes the internal quality which relatively continues and experienced by each individual of an organization or employee, this environment influences the behavior of each employee or individual. Meantime Litwin and Stringer as quoted by Bianca and Susihono (2012) stated that company environment is a concept which describes a subjective condition, organization environmental quality, where its existence is perceived and experienced by each member of the company. Davis and Newstorm (2002) as quoted by Syarif (2015) explained that company environmental as the is tangible or uncountable, however, it is still important for the company to observe this issue and maintain the records, because its existence can influence individual personality and the company employees. At the same time, Simamora (2001) in the Syarif (2015) also explained that company internal environment or physiological environment is a concept which describes the quality of company internal environment.

\subsection{Employees Performance}

Employees performance according to Mangkunegara (2005) as quated by Sulasri and Suhardi (2017), is the result of works achieved by the employee which meeting its quality or quantity requirements. This work is assigned to him/her as part of his/her job description. Moreover Simanjuntak (2011:1) defined that employees' performance is the parameter of achievement to achieve company mission and goals. In line with that perspective, Siagian (2014:166) defined the employees' performance as the status which can show the employee's capabilities in executing his/her assignment as required by the standards and targets set by the company or organization. Wibowo (2017:14) also states to achieve the company targets and goals, the company or managers need to arrange the implementation of the performance and to decide how the performance is to be measured and evaluated.

After understanding all the above definitions of the known variables, therefore, a research conceptual framework was developed to formulate the hypothesis, as below: 


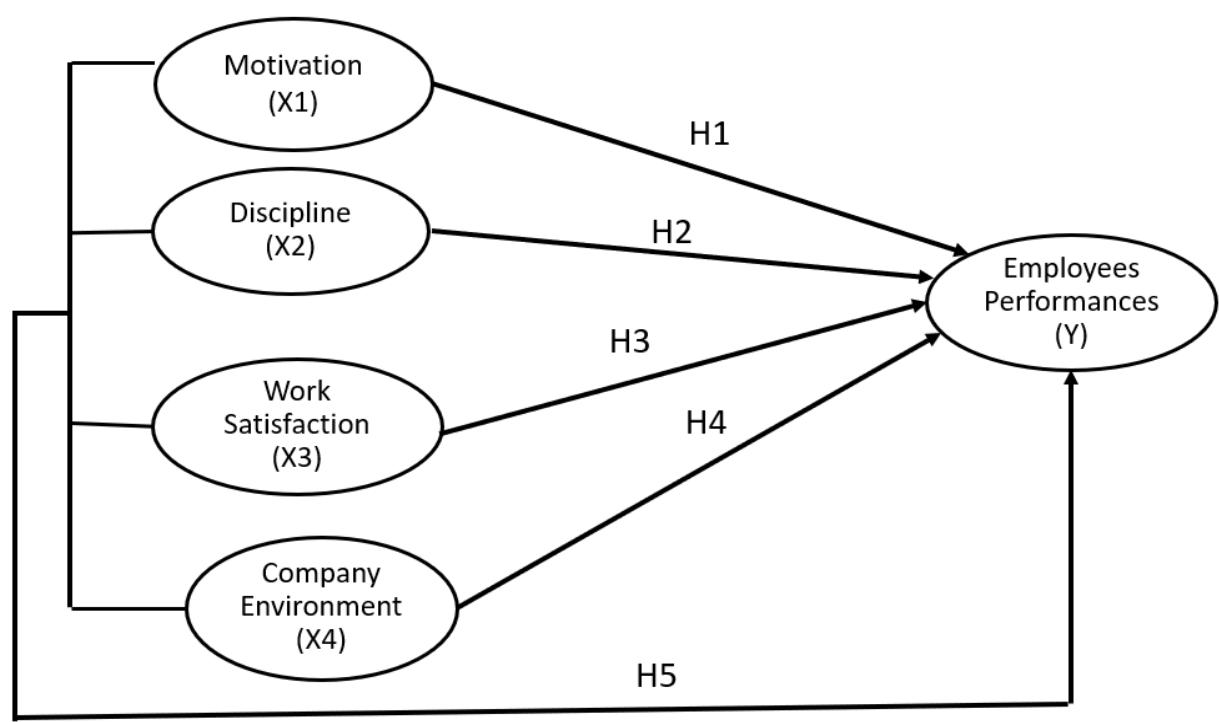

Fig. 1 Conceptual Framework

The purpose of the research which also known as hypothesis are developed and be detailed as below:

H1: To analyze the influence of motivation on the employee's performance at PT Profab Indonesia.

H2: To analyze the influence of discipline on the employee's performance at PT Profab Indonesia.

H3: To analyze the influence of work satisfaction on the employee's performance at PT Profab Indonesia.

H4: To analyze the influence of company environment on the employees' performance at PT Profab Indonesia.

H5: To analyze the influence of motivation, discipline, work satisfaction and company environment simultaneously on employees' performance at PT Profab Indonesia.

\subsection{Research Methodology}

1. Type or Method

Method of research is an ex-post facto research, where the research was empirically performed to discover the causing factors which undermines the events using a logical quantitative approach (Nazir, 2014).

2. Time and place of research

The research was done on December 2018 and January 2019, for two months and it was performed at PT Profab Indonesia, at Batu Merah, Kota Batam, Indonesia.

3. Respondents

Respondents were employees of PT Profab Indonesia with the numbers of 200 people. The population of PT Profab Indonesia is 400 people and using Slovin formula and random sampling methods the numbers of 250 people was defined.

The data was collected using questionnaires instrument, the questionnaires comprising variables of motivation, discipline, work satisfaction, company environment and employee's performance. Questionnaire is the instrument used to collect data and information which 
enable the data to be processed and analyzed and to study the attitudes, behaviors, beliefs and characteristics of the respondents. While to measure all the characteristics, Likert scale was used which will transform the data and numbers to be a variable dimension which can be measured, counted and processed as indicators or sub-indicators which can be defined as statements which represent the respondents (Nazir, 2014).

Some steps or statistical techniques which were used to analyze the data are as below:

a) Normality test

b) Multicollinearity test

c) $\mathrm{T}$ test

d) $\quad F$ test

e) Regression linear test

f) Determination coefficient (R square)

All the tests results can be seen in the Discussion section below.

The method used is a quantitative method and using statistic analysis computation with SPSS version 21. The research was meant to analyze the influence between variables, i.e. independent variables and dependent variable. Independent variables are motivation, discipline, work satisfaction and company environment, while dependent variable is employees' performance. The population of the company, PT Profab Indonesia is 400 people and 200 people were selected as the respondents of this research.

\section{FINDINGS}

Data which was obtained from the questionnaires distributed to the respondents were collected and processed using SPSS program using some methods such as normality test, $t$ test, $\mathrm{F}$ test, linear regression test and determination coefficient ( $\mathrm{R}$ square) test. $\mathrm{T}$ test was used to reveal whether partially each dependent variable such as motivation, discipline, work satisfaction and company environment individually is related or influencing the variable employees' performance. While $\mathrm{F}$ test is used to compare and indicate whether simultaneously independent variables i.e. motivation, discipline, work satisfaction and company environment are influencing dependent variable employees' performance.

At the meantime linear regression test was used to obtain the constant value and regression coefficient value from each independent variable towards their dependent variable. Determination coefficient or $\mathrm{R}$ square is used to obtain how big is the variation and how good is the relation and influences of those variables. All those relations and results will be discussed in this following Discussion section.

Below are the figure and tables which were used to analyze the relatedness and influences between the independent variables (motivation, discipline, work satisfaction and company environment) and dependent variable (employees' performance). From the below graphic (Figure 2) it is shown that all the points are focusing in the form of diagonal line, in the line or near to the line, which means that the residual values are normally distributed. The below table 1, Coefficients Table, will show the $t$ test result which will reveal the significant value of the independent variables (motivation, discipline, work satisfaction and company environment), VIF values (multicollinearity values) and t values and regression 
coefficients. Table 2, ANOVA table, will show the significant value and $\mathrm{F}$ value and Table 3 will show us R and Adjusted R Square value

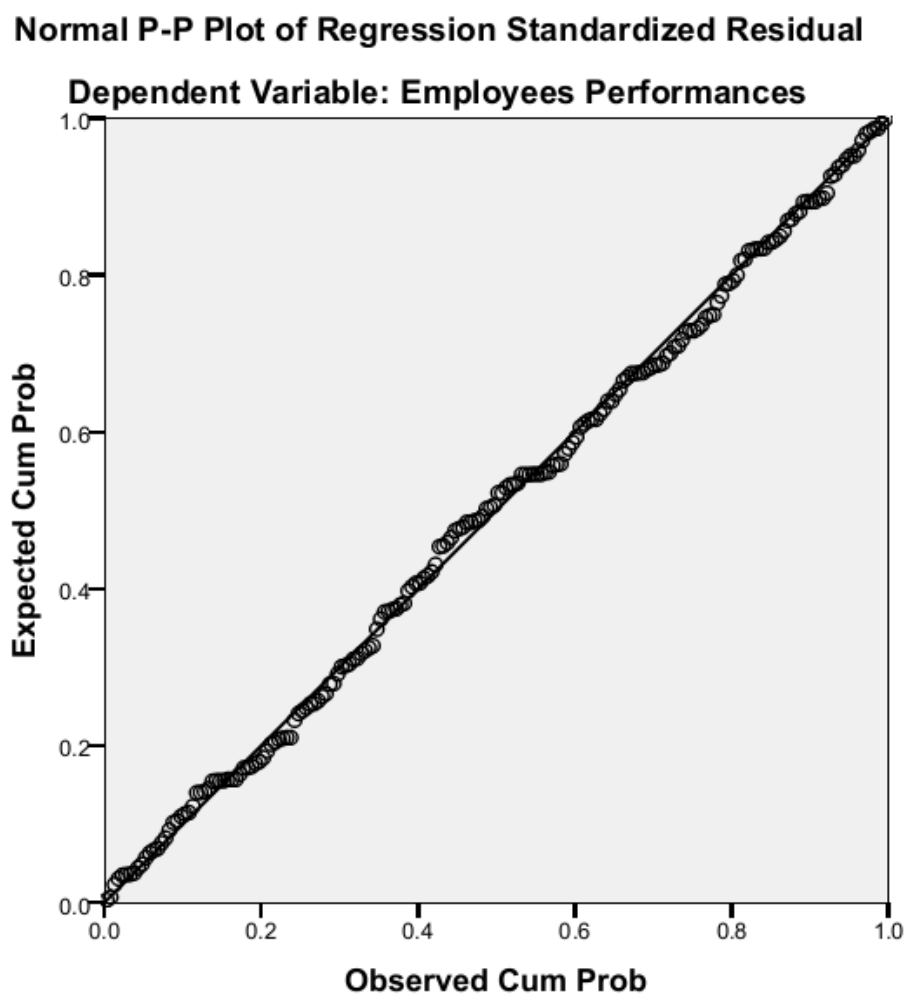

Fig. 1. Normality graphic P-P Plot of Regression

Table 1. T test

\begin{tabular}{|c|c|c|c|c|c|c|}
\hline \multicolumn{7}{|c|}{ Coefficients $^{a}$} \\
\hline \multirow{2}{*}{\multicolumn{2}{|c|}{ Model }} & \multicolumn{2}{|c|}{ Unstandardized Coefficients } & \multirow{2}{*}{$\begin{array}{c}\begin{array}{c}\text { Standardized } \\
\text { Coefficients }\end{array} \\
\text { Beta } \\
\end{array}$} & \multirow[b]{2}{*}{$\mathrm{t}$} & \multirow[b]{2}{*}{ Sig. } \\
\hline & & B & Std. Error & & & \\
\hline \multirow[t]{5}{*}{1} & (Constant) & 2.921 & 1.397 & & 2.091 & .038 \\
\hline & Motivation & .553 & .048 & .501 & 11.543 & .000 \\
\hline & Discipline & .257 & .041 & .236 & 6.283 & .000 \\
\hline & Work Satisfaction & .175 & .040 & .166 & 4.412 & .000 \\
\hline & Company Environment & .175 & .035 & .182 & 4.977 & .000 \\
\hline
\end{tabular}

a. Dependent Variable: Employees Performances

Table 2. F Test

ANOVA $^{a}$

\begin{tabular}{|ll|r|r|r|r|r|}
\hline \multicolumn{2}{|c|}{} & \multicolumn{1}{c|}{$\begin{array}{l}\text { Sum of } \\
\text { Squares }\end{array}$} & df & Mean Square & \multicolumn{1}{c|}{$\mathrm{F}$} & Sig. \\
\hline 1 & Regression & 828.841 & 4 & 207.210 & 264.033 & $.000^{\mathrm{b}}$ \\
& Residual & 153.034 & 195 & .785 & & \\
& Total & 981.875 & 199 & & & \\
\hline
\end{tabular}

a. Dependent Variable: Employees Performances

b. Predictors: (Constant), Company Environment, Discipline, Work Satisfaction, Motivation 
Table 3. Linear Regression

\begin{tabular}{|l|c|r|r|r|r|}
\hline \multicolumn{7}{|c|}{ Model Summary $^{\text {b }}$} \\
\hline Model & $\mathrm{R}$ & R Square & $\begin{array}{c}\text { Adjusted R } \\
\text { Square }\end{array}$ & $\begin{array}{c}\text { Std. Error of } \\
\text { the Estimate }\end{array}$ & $\begin{array}{c}\text { Durbin- } \\
\text { Watson }\end{array}$ \\
\hline 1 & $.919^{\mathrm{a}}$ & .844 & .841 & .886 & 1.919 \\
\hline
\end{tabular}

a. Predictors: (Constant), Company Environment, Discipline, Work Satisfaction, Motivation

b. Dependent Variable: Employees Performances

All the above data were processed using SPSS program and were discussed in the Discussion section below.

\section{DISCUSSION}

\subsection{Partial Analysis (See Table 1)}

a) Refer to hypothesis 1 (H1) which reveals that motivation has a significant influence on employees' performance. This is the result of calculation of $t$ test table which specifies that the calculated significant value is smaller than significant value of 0.05 and calculated $t$ value of 11.543 is bigger than $t$ table of 1.972. This means that $\mathrm{Ho}$ is rejected, and $\mathrm{Ha}$ is accepted and infers that motivation has a positive and significant influence on employees' performance.

b) Refer to hypothesis $2(\mathrm{H} 2)$ which reveals that discipline has a significant influence on employees' performance. This is the result of calculation of $t$ test table which specifies that the calculated significant value is smaller than significant value of 0.05 and calculated $t$ value of 6.283 is bigger than $t$ table of 1.972 . This means that Ho is rejected, and $\mathrm{Ha}$ is accepted and infers that discipline has a positive and significant influence on employees' performance.

c) Refer to hypothesis 3 (H3) which reveals that work satisfaction has a significant influence on employees' performance. This is the result of calculation of t test table which specifies that the calculated significant value is smaller than significant value of 0.05 and calculated $t$ value of 4.412 is bigger than $t$ table of 1.972. This means that Ho is rejected, and $\mathrm{Ha}$ is accepted and infers that work satisfaction has a positive and significant influence on employees' performance.

d) Refer to hypothesis 4 (H4) which reveals that company environment has a significant influence on employees' performance. This is the result of calculation of $t$ test table which specifies that the calculated significant value is smaller than significant value of 0.05 and calculated t value of 11.543 is bigger than table of 1.972. This means that Ho is rejected, and $\mathrm{Ha}$ is accepted and infers that company environment has a positive and significant influence on employees' performance.

4.2. Simultaneous Analysis (See Table 2) 
Refer to hypothesis 5 (H5) which reveals that motivation, discipline, work satisfaction and work environment simultaneously have significant influences on employees' performance. This is the result of calculated $F$ value of 264.033 which is bigger than $F$ table of 2.42. This means that Ho is rejected, and $\mathrm{Ha}$ is accepted and infers that simultaneously the motivation, discipline, work satisfaction and work environment have a positive and significant influence on employees' performance.

4.3. Coefficient Regression (See Table 1)

Coefficient regression which was obtained from the table is:

$\mathrm{Y}=2.921+0.553 \mathrm{X}_{1}+0.25 \mathrm{X}_{2}+0.175 \mathrm{X}_{3}+0.175 \mathrm{X}_{4}$

This means that constant value of the equation is 2.921 , while coefficient regression values of $X_{1}=+0.553, X_{2}=+0.25, X_{3}=+0.175$, and $X_{4}=+0.175$.

4.4. Coefficient Determination or R Square (See Table 3)

From the it was obtained that Adjusted R Square (coefficient determination) value of 0.841 is quite significant. This infers that the variation which gives motivation, discipline, work satisfaction and work satisfaction a simultaneous influence on employees' performance is quantified to $84.1 \%$, meanwhile the remainder of $15.9 \%$ is the existence of other factors or variables which were not explored in this journal. The correlation between independent variables (motivation, discipline, work satisfaction and work environment) on independent variable (employees' performance) is very strong which is represented with $\mathrm{R}$ value of 0.919 or it is closed to 1 .

\section{CONCLUSION}

5.1. It is concluded that partially motivation has a positive and significant influence on employees' performance at PT. Profab Indonesia. This means that with good stimulation of motivation will increase the employees' performance yield of the company.

5.2. It is concluded that partially discipline has a positive and significant influence on employees' performance at PT. Profab Indonesia. This means that with the improvement of discipline will increase the employees' performance yield of the company.

5.3. It is concluded that partially work satisfaction has a positive and significant influence on employees' performance at PT. Profab Indonesia. This means that with the increase of work satisfaction will increase the employees' performance yield of the company.

5.4. It is concluded that partially work environment has a positive and significant influence on employees' performance at PT. Profab Indonesia. This means that with the increase of work environment will increase the employees' performance yield of the company.

5.5. It is concluded that simultaneously motivation, discipline, work satisfaction, and work environment have positive and significant influences on employees' performance at PT. Profab Indonesia. This means that with the increase and improvement of motivation, discipline, work satisfaction and work environment will increase the employees' performance yield of the company.

\section{CONFLICT OF INTEREST}

The Author declares that they have no conflict of interest 


\section{SOURCE OF FINDING}

The Author received no specific finding for this work

\section{ETHICAL CLEARANCE}

None

\section{REFERENCES}

Bianca, A., Susihono W. 2012. Pengaruh Iklim Organisasi Dan Pengembangan Karir Terhadap Kepuasan Kerja Karyawan. Jurnal Spektrum Industri, Volume. 10, No. 2.

Gathungu, James, Wachira, H.W. 2013. Job Satisfaction Factors that Influence the Performance of Secondary School Principals in their Administrative Functions in Mombasa District, Kenya. International Journal of Education and Research. Vol. 1 No 2, pp. 257-270.

Handoko T, Hani. 2014. Manajemen Personalia dan Sumber Daya Manusia. Yogyakarta: BPFE.

Hasibuan, M.S.P. 2016. Manajemen Sumber Daya Manusia. Cetakan ke-20. Jakarta: Bumi Aksara.

Nazir, M. 2014. Metode Penelitian. Cetakan 10. Bogor. Ghalia Indonesia.

Robbins, S.P., Judge, T.A. 2013. Organizational Behaviour. 15th Edition. USA: Pearson Education.

Siagian, S.P. 2014. Manajemen Sumber Daya Manusia, Cetakan ke-20. Jakarta: Bumi Aksara.

Simanjuntak, P.J. 2011. Manajemen dan Evaluasi Kinerja. Edisi 3. Jakarta: Lembaga Penerbit FEUI.

Sulasri D., Suhardi. 2017. Pengaruh Kepemimpinan, Motivasi dan Kepuasan Kerja Terhadap Kinerja Pegawai Dinas Perhubungan Provinsi Riau. Ejournal Universitas Putera Batam.

Sukadi. 2016. Hubungan Motivasi Kerja dan Disiplin Kerja Terhadap Kinerja Guru Madrasah Tsanawiyah Al-Huda 1, Karangpandan. Tesis. IAIN Surakarta.

Supomo, R. Nurhayati, E. 2018. Manajemen Sumber Daya Manusia - untuk Mahasiswa dan Umum. Bandung: Yrama Widya.

Suprihati. 2014. Analisis Faktor-Faktor yang Mempengaruhi Kinerja Karyawan Perusahaan Sari Jati di Sragen. Jurnal Paradigma. Vol. 12. No.1.

Syarif, D. 2015. Teori-Teori Manajemen dan Organisasi - Iklim Organisasi. http://theorymanajemendanorganisasi.blogspot.com/2015/12/iklim-organisasi.html [11 Desember 2015].

Walsa, E. Ratnasari, S. L. 2016. Pengaruh Gaya Kepemimpinan dan Motivasi Terhadap Kinerja Karyawan PT. Citra Pembina Pengangkutan Industries Batam.Jurnal EKSEKUTIF, Vol. 13, No. 1. Hal 97-111.

Wibowo. 2017. Manajemen Kinerja. Edisi ke-5. Cetakan ke-12. Jakarta: PT. Rajagrafindo Persada.

Wijayanto, D. 2012. Pengantar Manajemen. Jakarta: PT. Gramedia. 